\title{
Lab Scale Fixed-Bed Reactor for Operando X-Ray Absorption Spectroscopy for Structure Activity Studies of Supported Metal Oxide Catalysts
}

\author{
Santhosh Kumar Matam • O. Korsak • \\ L. Bocher • D. Logvinovich $\cdot$ P. Hug • \\ A. Weidenkaff $\cdot$ D. Ferri
}

Published online: 7 September 2011

(C) Springer Science+Business Media, LLC 2011

\begin{abstract}
Lab scale fixed-bed reactor is applied for operando transmission X-ray absorption spectroscopy (XAS) for structure-activity studies of supported metal oxide catalysts under real reaction conditions. This setup includes many properties of an optimal fixed-bed reactor for operando transmission XAS studies. For instance, it is usable in a wide range of temperature (up to $1,000{ }^{\circ} \mathrm{C}$ ), pressure and space velocity. Besides, this operando setup can be used for transmission XAS measurements in a wide edge energy range. The potential of this reactor for operando transmission XAS is demonstrated by, as examples, the threeway catalytic performance of $\mathrm{Pd} / \mathrm{Al}_{2} \mathrm{O}_{3} / \mathrm{CeZrO}_{2}$ and $\mathrm{Rh} /$ $\mathrm{Al}_{2} \mathrm{O}_{3}$.
\end{abstract}

Keywords Operando spectroscopy $\cdot$ Lab scale fixed-bed reactor $\cdot$ X-ray absorption spectroscopy $\cdot$ Structure-activity relationships

\section{Introduction}

Operando spectroscopy is an important field of research in heterogeneous catalysis as it provides the know-how of a catalyst and hence, it can enhance our understanding of a

Electronic supplementary material The online version of this article (doi:10.1007/s11244-011-9745-3) contains supplementary material, which is available to authorized users.

S. K. Matam $(\bowtie) \cdot$ O. Korsak · L. Bocher · D. Logvinovich P. Hug · A. Weidenkaff · D. Ferri

Empa, Swiss Federal Laboratories for Materials Science and Technology, Laboratory for Solid State Chemistry and Catalysis, Ueberlandstrasse 129, CH-8600 Duebendorf, Switzerland

e-mail: santhosh.matam@empa.ch catalytic process. Given the importance of the operando methodology, a great deal of research has been dedicated to developing operando spectroscopy further for characterizing heterogeneous catalysts. For example, by improved reaction cell designs [1-8], coupling complementary techniques [2-15] and data analysis methods [16]. Reaction cells play an important role in operando spectroscopy as small variations in the reaction conditions (gas composition, gas flows, mass transfer effects, temperature, pressure, etc.) can dynamically transform catalyst structure which ultimately impact the catalyst performance [2]. This could provide a biased knowledge on the structure-activity relationships in catalysts. Different reaction cell designs such as capillary reactor, stainless steel block, diffuse reflectance cell (required when IR is coupled with XAS) and quartz tubes have been reported [1-10]. Undoubtedly, each of the cell designs has its own merits and demerits. These cells (except those reported very recently in [9] and [17]) were used assuming similar reaction conditions to those in a lab scale fixed-bed (or plug-flow) reactor [1-15]. In most of the cases it may be true however, some of the cell designs are often limited by gas flows, mass transfer effects, temperatures, etc.

These intrinsic limitations of reaction cells have been significantly reduced by capillary reactors for X-ray based techniques (XAS and XRD) [1]. Recently, improved but hazardous, Be tube (2-1.5 mm diameter and $10 \mathrm{~cm}$ length) cells were proposed over the conventional capillary reactors [18]. Our experience with capillary reactors revealed different disadvantages, for instance, pressure drop in the reactor, small gas flow rates, gradients in the large catalyst bed [19, 20] (e.g., $2 \mathrm{~cm} \mathrm{[1])} \mathrm{and} \mathrm{a} \mathrm{small} \mathrm{amount} \mathrm{of} \mathrm{the}$ catalyst mass probed despite large catalyst bed. Quartz reactors were also used however, with catalyst pellets instead of a catalyst bed comprising of catalyst sieve 
fraction, not a plug flow type reactor [7]. Very recently, a quartz reactor was reported for operando studies under conditions approaching those used for industrial operations $[9,17]$. However, the reactor reported in [9] is only usable for high energy X-rays (so that these X-rays can penetrate through the thick reactor wall). For low energy X-rays, the capillary reactors have been used. Though these capillaries provide, under certain conditions, realistic reaction conditions for operando XAS studies, there is still room for improved cell designs [17].

In the present study, we report lab scale fixed-bed reactor for operando transmission XAS studies under real conditions (similar to those used for a commercial operation) using low energy X-rays. We have realized this by adapting our lab scale fixed-bed reactor comprising of quartz reactor ( $2 \mathrm{~cm}$ diameter and $45 \mathrm{~cm}$ length), oven, gas manifold (Bronkhorst) and mass spectrometer (MS; Balzers, Omnistar) for on line analysis of the reactor outlet at the beam line X1 of Hasylab (DESY, Hamburg, Germany).

\section{Experimental}

\subsection{Reactor Setup}

The detailed description of the setup is reported elsewhere [21]. Briefly, the reactor is typically loaded with $400 \mathrm{mg}$ of catalyst (fraction of 100-150 $\mu \mathrm{m}$ ) that resulted in a bed length of ca. $2 \mathrm{~mm}$. The reactor is fixed in a horizontal oven placed between $\left(I_{\mathrm{o}}\right)$ and $\left(I_{1}\right)$ chambers and the system is aligned such that the X-ray beam $(8 \times 1 \mathrm{~mm})$ passes through the length of the reactor and the catalyst bed. In contrast, for a capillary reactor the X-ray beam bisects the middle of the capillary wall (or an in situ cell) and the catalyst bed [19-21]. For comparative purposes, some of the experiments were also repeated with a capillary (2.8 $\mathrm{mm}$ internal diameter and $7.5 \mathrm{~cm}$ length (Hilgenberg)) at the SuperXAS beamline, SLS (Villigen, Switzerland). The capillary is loaded with ca. $50 \mathrm{mg}$ of catalyst (fraction of $100-150 \mu \mathrm{m}$ ) which resulted in a bed length of ca. $5 \mathrm{~mm}$.

The potential of the operando setup was explored by studying various supported (e.g., $\mathrm{Pd}, \mathrm{Pt}$ or $\mathrm{Rh}$ on $\mathrm{Al}_{2} \mathrm{O}_{3}$, $\mathrm{CeZrO}_{2}, \mathrm{Al}_{2} \mathrm{O}_{3} / \mathrm{CeZrO}_{2}$ or perovskites) catalysts on the three-way catalytic (TWC) performance, oxidation and reduction reactions. Here two examples will be discussed: (i) comparison of TWC performance of $\mathrm{Pd} / \mathrm{Al}_{2} \mathrm{O}_{3} / \mathrm{CeZrO}_{2}$ conducted with the present setup and with a capillary reactor and (ii) the effect of thermal aging on the redox properties of $\mathrm{Rh}$ supported on $\mathrm{Al}_{2} \mathrm{O}_{3}$ and its influence on the TWC properties. For the second example, the fresh and hydrothermally aged $2 \mathrm{wt} \% \mathrm{Rh} / \mathrm{Al}_{2} \mathrm{O}_{3}$ are subjected to $\mathrm{H}_{2}$ TPR and sequential $\mathrm{CO}$ and NO pulse experiments.

\subsection{Catalysts}

The catalysts $1.6 \mathrm{wt} \% \quad \mathrm{Pd} / \mathrm{Al}_{2} \mathrm{O}_{3} / \mathrm{CeZrO}_{2}$ (BET surface area: $118 \mathrm{~m}^{2} / \mathrm{g}$ ) and $2 \mathrm{wt} \% \mathrm{Rh} / \mathrm{Al}_{2} \mathrm{O}_{3}$ (BET: $134 \mathrm{~m}^{2} / \mathrm{g}$ ) were kindly provided by Umicore, Germany. The fresh catalysts were calcined in air at $500{ }^{\circ} \mathrm{C}$ for $4 \mathrm{~h}$. A portion of the fresh catalyst $\mathrm{Rh} / \mathrm{Al}_{2} \mathrm{O}_{3}$ was hydrothermally aged (in 10 vol\% $\mathrm{H}_{2} \mathrm{O}, 10$ vol\% $\mathrm{O}_{2}$ in $\mathrm{N}_{2}$ ) at $1,000{ }^{\circ} \mathrm{C}$ for $16 \mathrm{~h}$ (BET: $68 \mathrm{~m}^{2} / \mathrm{g}$ ).

\subsection{Operando X-Ray Absorption Spectroscopy}

The three-way catalytic performance of $\mathrm{Pd} / \mathrm{Al}_{2} \mathrm{O}_{3} / \mathrm{CeZrO}_{2}$ was measured with the present setup and the capillary reactor. The feed composition was $1,300 \mathrm{ppm} \mathrm{CH}_{4}$, 7,000 ppm CO, 1,600 ppm NO and 5,300 ppm $\mathrm{O}_{2}$ in He. The total flow rate was either $400 \mathrm{~mL} / \mathrm{min}$ (for the present setup) or $50 \mathrm{~mL} / \mathrm{min}$ (for the capillary reactor). In the former, the same flow rate was detected at the outlet of the reactor. However, the flow rate of only $30 \mathrm{~mL} / \mathrm{min}$ was detected at the outlet of the capillary. This indicates that there was a pressure drop in the reactor which could not be avoided even at lower flow rates. The catalyst bed temperature in the present setup is measured through the reactor wall (by directly placing the K-type thermocouple on the reactor wall), whereas only hot air temperature estimation between the reactor and oven (air blower) is considered for a capillary reactor $[1,20,21]$.

Temperature programmed reduction with $\mathrm{H}_{2}\left(\mathrm{H}_{2}-\mathrm{TPR}\right)$ of fresh and aged $\mathrm{Rh} / \mathrm{Al}_{2} \mathrm{O}_{3}$ were performed between room temperature and $450{ }^{\circ} \mathrm{C}$. Prior to $\mathrm{H}_{2}$-TPR experiments, catalysts were calcined in air at $500{ }^{\circ} \mathrm{C}$ for $30 \mathrm{~min}$. After $\mathrm{H}_{2}$-TPR, catalysts were flushed with $\mathrm{He}$ for $15 \mathrm{~min}$ at $450{ }^{\circ} \mathrm{C}$ and subsequently sequential pulses of $\mathrm{CO} / \mathrm{He}$ and $\mathrm{NO} / \mathrm{He}$ for $500 \mathrm{~s}$ each were performed. In total of eight cycles $(\mathrm{CO}+\mathrm{NO}$ pulses gives rise to a cycle), first two cycles were considered to allow the system to reach steadystate.

X-ray absorption spectroscopy (XAS) data were collected in the transmission mode. X-ray absorption near edge structure (XANES) spectra were measured at the $\mathrm{Pd}$ K-edge $(24.35 \mathrm{keV})$ to study the behaviour of Pd during the TWC over $\mathrm{Pd} / \mathrm{Al}_{2} \mathrm{O}_{3} / \mathrm{CeZrO}_{2}$. XANES and EXAFS (extended X-ray absorption fine structure) spectra were obtained at the Rh K-edge $(23.22 \mathrm{keV})$ using Rh foil as reference. During $\mathrm{H}_{2}$-TPR, XANES spectra were measured. Quick EXAFS spectra (125 s per spectrum) were obtained during the CO/NO pulse experiment. WINXAS v3.1 software was used for data evaluation [22]. 


\section{Results and Discussion}

3.1 The Potential of the Operando Setup is Demonstrated by Probing the TWC Performance of $\mathrm{Pd} / \mathrm{Al}_{2} \mathrm{O}_{3} / \mathrm{CeZrO}_{2}$ and the Redox Properties of $\mathrm{Rh}$ in Fresh and Aged Catalysts

\subsubsection{Three-way catalytic (TWC) performance of $\mathrm{Pd} /$ $\mathrm{Al}_{2} \mathrm{O}_{3} / \mathrm{CeZrO}_{2}$}

The potential of the operando setup is assessed by comparing the TWC performance of $\mathrm{Pd} / \mathrm{Al}_{2} \mathrm{O}_{3} / \mathrm{CeZrO}$ obtained with the lab scale fixed-bed reactor and capillary. For the sake of clarity, only the oxidation of methane profiles and the corresponding XANES spectra are shown in Fig. 1. Starting with the data obtained on the present setup, the maximum conversion of methane during heating is observed at around $445^{\circ} \mathrm{C}$ and the conversion remains the same up to $860{ }^{\circ} \mathrm{C}$ (Fig. 1a). However, while cooling conversion remains the maximum up to $680{ }^{\circ} \mathrm{C}$. Typical loss in the combustion activity is then observed between 680 and $450{ }^{\circ} \mathrm{C}$ with a maximum loss of methane conversion at around $589^{\circ} \mathrm{C}$. It is noteworthy that at $325{ }^{\circ} \mathrm{C}$ (either heating or cooling), around $30 \%$ conversion of methane is observed. The corresponding XANES measured during heating and cooling are shown in
Fig. 1a. The black spectrum (see heating) indicates the initial state of palladium in the catalyst, which is the oxidized state [21]. During heating, $\mathrm{PdO}_{x}$ is reduced at around $650{ }^{\circ} \mathrm{C}$ and it remains the same up to $860{ }^{\circ} \mathrm{C}$. While cooling, the reduced Pd only slightly reoxidizes at around $200{ }^{\circ} \mathrm{C}$. These results reveal the occurrence of a redox cycle (reduction and re oxidation of $\mathrm{PdO}_{x}$ ) in the catalyst under these experimental conditions. The data obtained with the capillary reactor is different as shown in Fig. 1b. No methane conversion is observed at $325^{\circ} \mathrm{C}$ (either heating or cooling) and the corresponding XANES spectra show no reduction of $\mathrm{PdO}_{x}$ in the catalyst even at around $680{ }^{\circ} \mathrm{C}$ (Fig. 1b). These results can be attributed to the following observations made during the experiment in the capillary reactor: (i) pressure drop in the reactor, (ii) the way the catalyst bed temperature is measured (see Fig. 2 and Sect. 2.3), (iii) space velocity or (iv) temperature (maximum $T$ that could be attained with this capillary setup is $680^{\circ} \mathrm{C}$ ).

\subsubsection{XANES during $\mathrm{H}_{2}$-TPR}

The reducibility of $\mathrm{Rh}$ in fresh and aged catalysts is shown in Fig. 3. The initial state of Rh after oxidative pretreatment and before $\mathrm{H}_{2}$ switch (black spectra) is a completely oxidized state [19]. In the fresh catalyst, significant
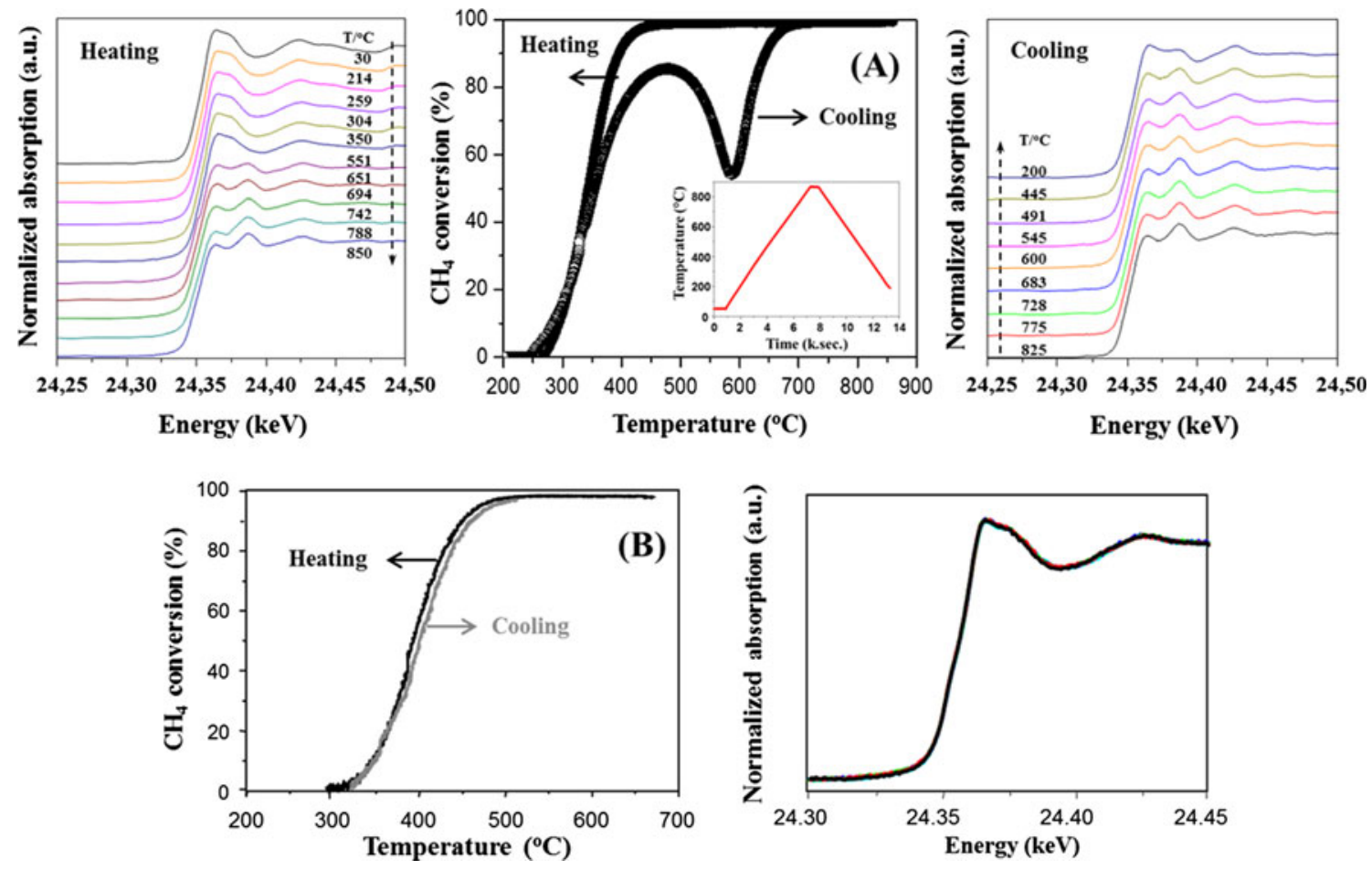

Fig. 1 Three-way catalytic performance of $\mathrm{Pd} / \mathrm{Al}_{2} \mathrm{O}_{3} / \mathrm{CeZrO}_{2}$ obtained with the present setup (a) and capillary reactor (b). See text for experimental conditions. Temperature profile of the catalyst bed measured through the reactor wall is shown in the inset 
Fig. 2 Photographs (above) and schematic representation (below) of the lab-scale fixed bed reactor (a) and capillary reactor $(\mathbf{b})$
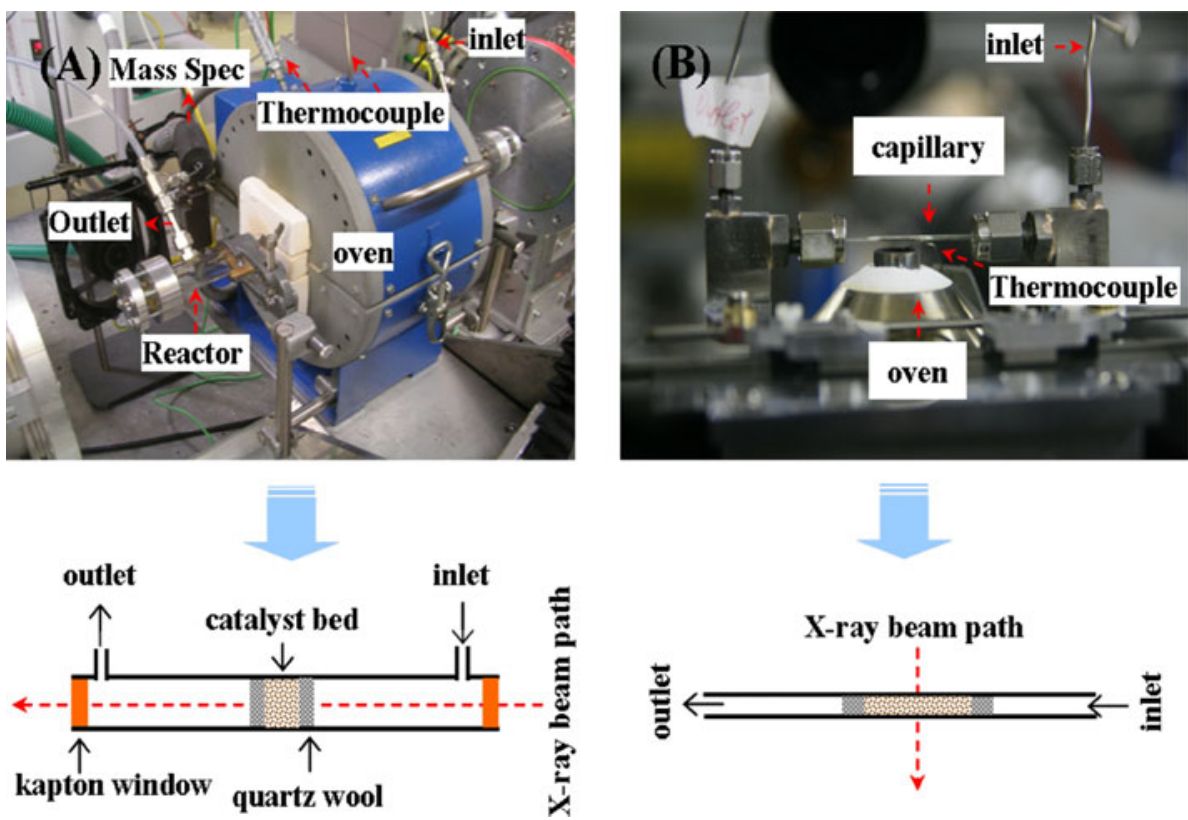

reduction of $\mathrm{Rh}$ is observed already at $30{ }^{\circ} \mathrm{C}$ (red spectrum) as evidenced by the decreased intensity of the white line that is accompanied by a red shift of the edge energy and appearance of a new peak at $\Delta \mathrm{keV}$ of 0.0324 . These features are characteristic for metallic Rh [19]. Complete reduction of $\mathrm{Rh}$ is essentially observed at around $100{ }^{\circ} \mathrm{C}$ (pink spectrum) after which the process is minimal even up to $450{ }^{\circ} \mathrm{C}$ (green spectrum). In marked contrast, most of $\mathrm{Rh}$ in the aged catalyst is not sensitive to reduction even up to $450{ }^{\circ} \mathrm{C}$ as evidenced by the negligible decrease in intensity of the spectra taken at $30{ }^{\circ} \mathrm{C}$ (initial spectrum, black) and $450{ }^{\circ} \mathrm{C}$ (green). This indicates that only a small fraction of $\mathrm{Rh}$ is reducible in the catalyst, in line with literature [2325]. For example, it was shown that the reducibility of $\mathrm{Rh}$ in $0.5 \mathrm{wt} \% \mathrm{Rh} / \mathrm{Al}_{2} \mathrm{O}_{3}$ decreases with increasing aging temperature by $\mathrm{H}_{2}$-TPR. And, only $14 \% \mathrm{Rh}$ is reducible in the catalyst that was aged at $702{ }^{\circ} \mathrm{C}$ for $1 \mathrm{~h}$ [25]. However, such a behaviour of $\mathrm{Rh}$ is not yet completely understood and different mechanisms were proposed [23, 26]. Our recent findings by UltraSTEM suggest that the diffusion of $\mathrm{Rh}$ into the alumina lattice is responsible for highly reduction resistant $\mathrm{Rh}$ oxide formation [27].

\subsubsection{Quick EXAFS during Sequential CO and NO Pulses over Reduced Catalysts}

The reaction between $\mathrm{CO}$ and $\mathrm{NO}$ is one of the most important steps in three-way catalytic processes for the oxidation and reduction of $\mathrm{CO}$ and $\mathrm{NO}$, respectively, over $\mathrm{Rh}$ [28-31]. Thus, the behaviour of Rh during the transient reaction between $\mathrm{CO}$ and $\mathrm{NO}$ over the reduced fresh $\mathrm{Rh} /$ $\mathrm{Al}_{2} \mathrm{O}_{3}$ catalyst at $450{ }^{\circ} \mathrm{C}$ is studied by quick EXAFS (Fig. 4). Every $\mathrm{CO}$ or NO gas pulse was sequentially switched on for $500 \mathrm{~s}$ for a total of eight cycles, starting with $\mathrm{CO}$ pulse.

During each pulse, four quick EXAFS were measured. For the sake of clarity, only the last spectrum (i.e., the fourth spectrum) from each switch and two spectra from a total of eight spectra for a complete $\mathrm{CO} / \mathrm{NO}$ cycle are shown in Fig. 4. Only three complete switches from a total of eight are shown for MS data (Fig. 4). A set of 16 quick EXAFS during two complete $\mathrm{CO}$ and $\mathrm{NO}$ cycles can be found in ESI (Fig. S1).

After a reductive pretreatment, $\mathrm{Rh}$ is in a completely reduced state. A subsequent $\mathrm{CO}$ switch does not change the state of $\mathrm{Rh}$ in the catalyst as evident from the spectrum (black) in Fig. 4 that is similar to the spectrum (green) taken at $450{ }^{\circ} \mathrm{C}$ during $\mathrm{H}_{2}$-TPR (Fig. 3). The reduced $\mathrm{Rh}$ is partly reoxidized upon subsequent $\mathrm{NO}$ switch indicating that $\mathrm{Rh}$ is redox active in the fresh catalyst. A sharp evolution of products $\mathrm{CO}_{2}$ and $\mathrm{N}_{2}$ is also evident from the corresponding MS data on either a $\mathrm{CO}$ or NO switch. Based on these observations it can be suggested that the redox cycle involving surface reaction between $\mathrm{CO}$ and $\mathrm{NO}$ is occurring on $\mathrm{Rh}$ as shown in Eq. 1.

$\mathrm{CO}+\mathrm{NO} \rightarrow \mathrm{CO}_{2}+1 / 2 \mathrm{~N}_{2}$

The mass fraction $(\mathrm{m} / \mathrm{z}=44)$ of $\mathrm{CO}_{2}$ overlaps with that of $\mathrm{N}_{2} \mathrm{O}$. Thus the formation of the latter cannot be ruled out according to the Eq. 2.

$\mathrm{CO}+2 \mathrm{NO} \rightarrow \mathrm{CO}_{2}+\mathrm{N}_{2} \mathrm{O}$

Evidence on the occurrence of these two reactions is reported elsewhere [16], where we have studied $\mathrm{CO} / \mathrm{NO}$ cycles on on $\mathrm{Rh} / \mathrm{A}_{2} \mathrm{O}_{3}$ by energy dispersive EXAFS/ DRIFTS/MS. It was observed that upon a CO switch the 

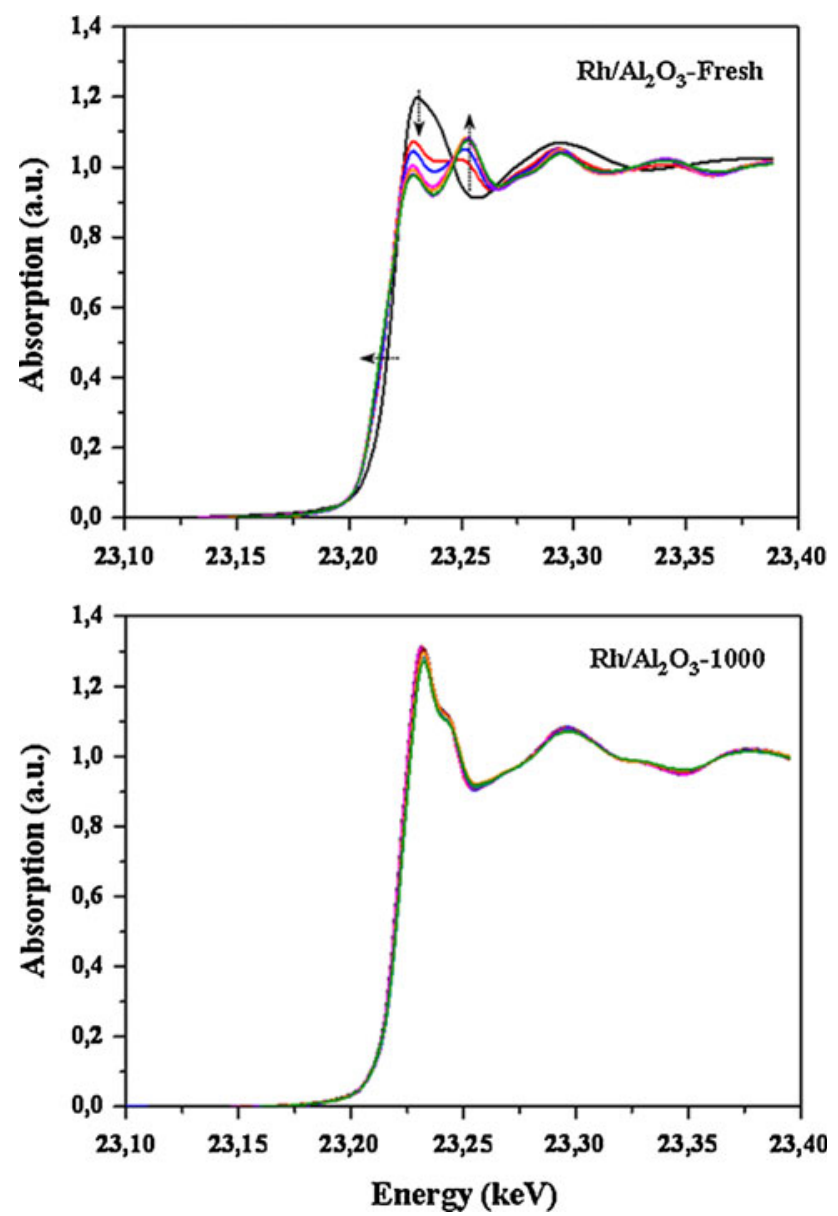

Fig. 3 XANE spectra of the catalysts during heating from 30 to $450{ }^{\circ} \mathrm{C}\left(5{ }^{\circ} \mathrm{C} / \mathrm{min}\right)$ in a flow of $5 \mathrm{vol} \% \mathrm{H}_{2} / \mathrm{He}$. Initial spectra at $30{ }^{\circ} \mathrm{C}$ (black) and spectra at $450{ }^{\circ} \mathrm{C}$ (green)

catalyst surface is populated by differently adsorbed $\mathrm{CO}$ species. A subsequent $\mathrm{NO}$ switch produces $\mathrm{CO}_{2}$ via $\mathrm{Rh}$ NCO species (Eq. 1) and $\mathrm{N}_{2} \mathrm{O}$ via formation of $\mathrm{Rh}-$ $\mathrm{NO}^{-}$(Eq. 2).

Interestingly, the relative intensity of MS signal of $\mathrm{m} /$ $z=44$ associated to $\mathrm{CO}_{2}$ and $\mathrm{N}_{2} \mathrm{O}$ is different between the $\mathrm{CO} \rightarrow \mathrm{NO}$ and the NO $\rightarrow \mathrm{CO}$ switches (Fig. 4). The signal intensity is always higher for the latter switch than for the former. It may suggest that during $\mathrm{NO} \rightarrow \mathrm{CO}$ switch the formation of products is significant, especially $\mathrm{N}_{2} \mathrm{O}$, than that during $\mathrm{CO} \rightarrow \mathrm{NO}$ switch. This could be due to more available Rh sites for NO to form species like Rh$\mathrm{NO}^{-}$and to the partially oxidized state of $\mathrm{Rh}$, which are responsible for $\mathrm{N}_{2} \mathrm{O}$ formation [16].

In contrast to the fresh catalyst, as evident from Fig. 3, most of $\mathrm{Rh}$ is not redox active in the hydrothermally aged catalyst during $\mathrm{CO} / \mathrm{NO}$ cycles (Fig. S1 in ESI). This could explain the poor TWC performance of the catalyst [24, 25].
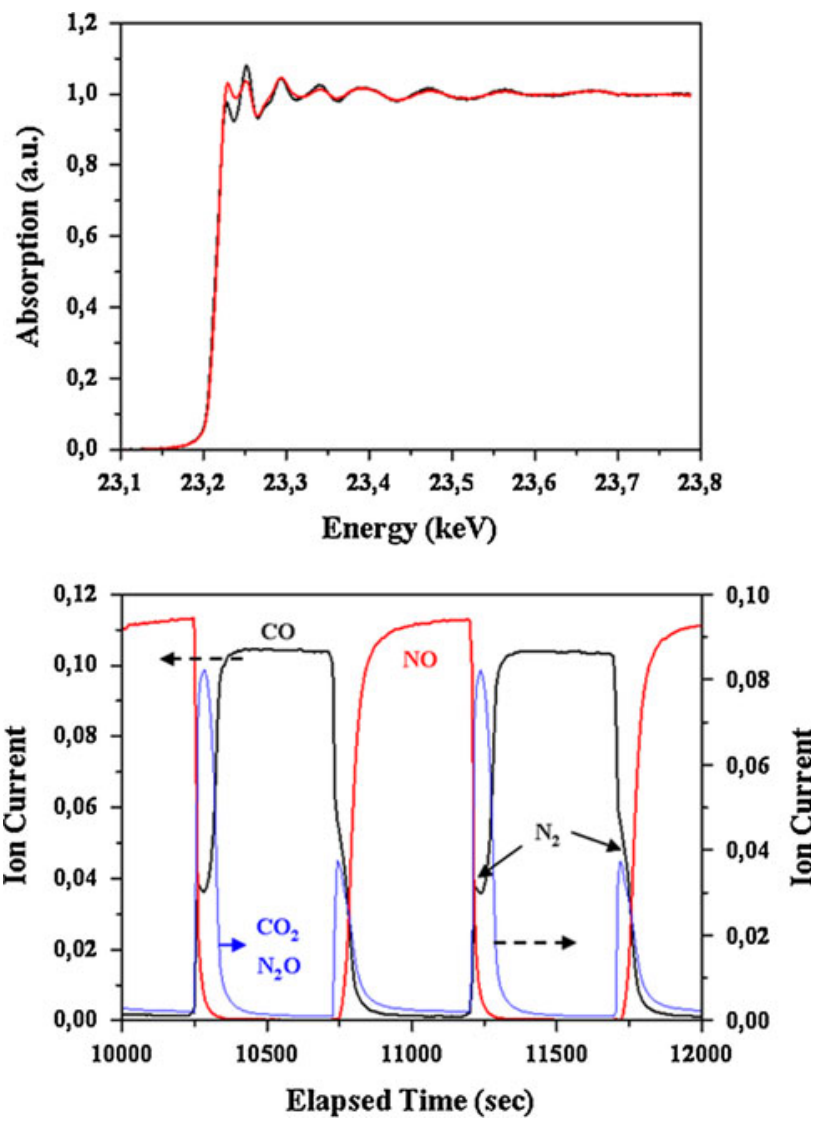

Fig. 4 Sequential pulses between 1 vol\% $\mathrm{CO} / \mathrm{He}$ and 1 vol $\% \mathrm{NO} / \mathrm{He}$ over pre-reduced fresh $\mathrm{Rh} / \mathrm{Al}_{2} \mathrm{O}_{3}$ catalyst at $450{ }^{\circ} \mathrm{C}$. The quick EXAFS during pulses (above) and relative concentration of reactants ( $\mathrm{CO}$ and $\mathrm{NO}$ ) and products $\left(\mathrm{CO}_{2}, \mathrm{~N}_{2} \mathrm{O}\right.$ and $\left.\mathrm{N}_{2}\right)$ at the outlet of the reactor is analyzed on-line by MS (below)

\subsection{Advantages and Limitations of the Operando Setup}

\subsubsection{Advantages}

The photographs and schematic diagrams of the operando setup and capillary reactors are depicted in Fig. 2. The main advantages of the setup are as follows:

(i) The typical catalyst bed length is around $2 \mathrm{~mm}$ in the reactor which is much smaller than that often used in a conventional operando reaction cell for example $1-2 \mathrm{~cm}[1,4]$. This implies that the concentration gradients within the solid phase and gas-solid phases can be greatly reduced.

(ii) The X-ray beam probes the whole catalyst bed length (from front to rear), averaging out, if any, gradients in the catalyst bed of $2 \mathrm{~mm}$. This in turn prevents the loss of spatiotemporal information [9].

(iii) The volume of the catalyst probed in the reactor is more than one order of magnitude larger than that in 
conventional operando reaction cells. This allows to obtain high-quality spectra.

(iv) The setup allows for studying catalysis under a large window of space velocities which is extremely limited with operando reaction cells. This implies that a reaction can be performed under a kinetically controlled regime.

The above advantages demonstrate that accurate and reliable data on the catalyst structure activity relationships can be obtained with this setup. Furthermore, the reactor setup can directly be coupled with operando UV-Vis and Raman spectroscopic techniques.

\subsubsection{Limitations}

The setup is limited by the large reactor volume that has the following main implications:

(i) The catalyst bed length is much smaller (between 2 and $4 \mathrm{~mm}$, which is suitable for operando studies) than that of in an optimal reactor (in this case it should have been $20 \mathrm{~cm}$ ). This is a compromise between the bed length and spatiotemporal information along the bed, the smaller the bed the better the received spatiotemporal information.

(ii) Though the setup can be used in a wide space velocity, it may not be suitable for very low space velocity regimes.

(iii) Unlike capillary reactors, this setup cannot be coupled with XRD.

\section{Conclusions}

A lab scale fixed-bed reactor is presented that allows to conduct operando transmission X-ray absorption spectroscopy studies under an optimal reaction conditions of a fixed-bed reactor and to obtain high quality data. With this setup the loss of spatiotemporal information can be greatly avoided. The obtained results demonstrate the participation of Pd and Rh redox cycle in TWC process which in turn proved the credibility of the setup.

Acknowledgments The authors kindly acknowledge the financial support of Empa and Umicore, H. Altorfer and the mechanical workshop of Empa for the modification of the operando XAS setup. The team at beamline X1 at Hasylab (DESY, Germany) and SuperXAS beamline (SLS, Switzerland) are thanked for the beamtime allocation and technical support.

\section{References}

1. Clausen BS, Fabius GSB, Villadsen J, Feidenhans'1 R, Topsoe H (1991) J Catal 132:524

2. Topsoe H (2003) J Catal 216:155

3. Sankar G, Thomas JM (1999) Top Catal 8:1

4. Odzak JF, Argo AM, Lai FS, Gates BC, Pandya K, Feraria L (2001) Rev Sci Instrum 72:3943

5. Weckhuysen BM (2002) Chem Commun 58:97

6. Grunwaldt J-D, Clausen BS (2002) Top Catal 18:37

7. Bare SR, Mickelson GE, Modica FS, Ringwelski AZ, Yang N (2006) Rev Sci Instrum 77:023105

8. Mesu JG, van der Eerden AMJ, de Groot FMF, Weckhuysen BM (2005) J Phys Chem B 109:4042

9. O'Brien MG, Beale AM, Jacques SDM, Michiel MD, Weckhuysen BM (2010) Appl Catal A 391:468

10. Tromp M, Sietsma JRA, van Bokhoven JA, van Strijdonck GPF, van Haaren RJ, van der Eerden AMJ, van Leeuwen PWNM, Koningsberger DC (2003) Chem Commun 1:128

11. Nijhuis TA, Tinnemans SJ, Visser T, Weckhuysen BM (2003) Phys Chem Chem Phys 5:4361

12. Hunger M, Wang W (2004) Chem Commun 5:584

13. Thibault-Starzyk F, Gil B, Aiello S, Chevreau T, Gilson JP (2004) Micropor Mesopor Mater 67:107

14. Grunwaldt J-D, Caravati M, Hannemann S, Baiker A (2004) Phys Chem Chem Phys 6:3037

15. Brueckner A (2005) Chem Commun 13:1761

16. Ferri D, Santhosh Kumar M, Wirz R, Eyssler A, Korsak O, Hug P, Weidenkaff A, Newton MA (2010) Phys Chem Chem Phys 12:5634

17. Bare SR, Kelly SD, Ravel B, Greenlay N, King L, Mickelson GE (2010) Phys Chem Chem Phys 12:7702

18. Bare SR, Yang N, Kelly SD, Mickelson GE, Modica FS (2007) Catal Today 126:18

19. Grunwaldt J-D, Hannemann S, Schroer CG, Baiker A (2006) J Phys Chem B 110:8674

20. Kimmerle B, Grunwaldt J-D, Baiker A, Glatzel P, Boye P, Stephan S, Schroer CG (2009) J Phys Chem C 113:3037

21. Santhosh Kumar M, Aguirre MH, Weidenkaff A, Ferri D (2010) J Phys Chem C 114:9439

22. Ressler T (1998) J Synchrotron Radiat 5:118

23. Dohmae K, Nagai Y, Tanabe T, Suzuki A, Inada Y, Nomura M (2008) Surf Interface Anal 40:1751

24. Yao HC, Stepien HK, Gandhi HS (1980) J Catal 61:547

25. Wong C, McCabe RW (1989) J Catal 119:47

26. Dohmae K, Nonaka T, Seno Y (2005) Surf Interface Anal 37:115

27. Bocher L, Aguirre MH, March K, Kumar MS, Ferri D, Colliex C, Stéphan O (2010) 7th International Microscopy Congress (IMC17). Rio de Janeiro, Brazil

28. Peden CHF, Goodman DW, Blair DS, Berlowitz PJ, Fisher GB, Oh SH (1988) J Phys Chem 92:1563

29. Permana H, Ng KYS, Peden CHF, Schmieg SJ, Belton DN (1995) J Phys Chem 99:16344

30. Dent AJ, Evans J, Fiddy SG, Jyoti B, Newton MA, Tromp M (2007) Angew Chem Int Ed 46:5356

31. Chafik T, Kondarides DI, Verykios XE (2000) J Catal 190:446 